\title{
Pengaruh Pembelajaran Kooperatif Jigsaw Terhadap Kemampuan Pemecahan Masalah Matematik Siswa
}

\author{
Minarti Juliana ${ }^{1}$, Minta Ito Simamora ${ }^{2}$, Dini Astika ${ }^{3}$ \\ ${ }^{1}$ Prodi Pendidikan Matematika, FKIP, STKIP PADANG LAWAS, Sibuhuan-Padang Lawas 22763 \\ ${ }^{2,3}$ Prodi Pendidikan Matematika, FKIP, Universitas Al-Washliyah, Medan-Indonesia 20155 \\ Email: minartijuliana@gmail.com
}

\begin{abstract}
ABSTRAK
Penelitian ini bertujuan untuk mengetahui: pengaruh pembelajaran kooperatif jigsaw terhadap kemampuan pemecahan masalah matematika siswa MTs Al-Washliyah. Penelitian ini merupakan penelitian kuantitatif eksperimen. Populasi penelitian ini adalah siswa kelas VII MTs AlWashliyah. Untuk sampel penelitian ini adalah kelas VIIA-1 dan kelas VIIA-2. Analisis data dilakukan dengan pretest-posttest control group design. Hasil penelitian menunjukkan bahwa terdapat pengaruh pembelajaran kooperatif jigsaw terhadap kemampuan pemecahan masalah matematika siswa MTs Al-Washliyah 16 Perbaungan. Hal ini terlihat dari hasil kemampuan pemecahan masalah matematika siswa kelas eksperimen lebih tinggi daripada kemampuan pemecahan masalah matematika kelas kontrol setelah diberikan pembelajaran dan posttest, dimana diketahui berdasarkan perbandingan jumlah nilai dan rata-rata posttest kedua kelas sampel, yaitu jumlah nilai kelas eksperimen $=2727,5>$ jumlah nilai kelas kontrol $=2490$, dan rata-rata kelas eksperimen $=75,76>$ rata-rata kelas kontrol $=69,17$.
\end{abstract}

Kata kunci: Jigsaw, Kemampuan Pemecahan Masalah

\begin{abstract}
This study aims to determine: the effect of jigsaw cooperative learning on the mathematical problem solving ability of MTs Al-Washliyah students. This research is an experimental quantitative research. The population of this study was the seventh grade students of MTs AlWashliyah. The samples for this study were class VIIA-1 and class VIIA-2. Data analysis was carried out using a pretest-posttest control group design. The results showed that there was an effect of jigsaw cooperative learning on the mathematical problem solving ability of the students of MTs Al-Washliyah 16 Perbaungan. This can be seen from the results of the experimental class students' mathematical problem solving abilities which are higher than the control class mathematics problem solving abilities after being given learning and posttest, which is known based on the comparison of the total scores and posttest averages of the two sample classes, namely the total value of the experimental class $=2727,5>$ the total value of the control class $=2490$, and the average of the experimental class $=75.76>$ the average of the control class $=69.17$.
\end{abstract}

Keyword: Jigsaw, Problem Solving Ability

\section{A. Pendahuluan}

Matematika merupakan salah satu pengetahuan manusia yang paling bermanfaat dalam kehidupan. Hampir setiap bagian dari hidup kita mengandung matematika sehingga anak-anak membutuhkan pengalaman yang tepat untuk bisa menghargai kenyataan bahwa matematika adalah penting untuk masa depan mereka. Oleh karena itu, matematika dijadikan sebagai salah satu pelajaran pokok yang diajarkan di sekolah, yang peranannya penting bagi siswa. Seperti yang dinyatakan oleh 
Suherman (2001:54) bahwa "Matematika yang diajarkan di sekolah mempunyai peranan sangat penting, karena para siswa memerlukan matematika untuk memenuhi kebutuhan praktis dan memecahkan masalah dalam kehidupan sehari-hari, dan untuk membantu memahami bidang studi lain seperti fisika, kimia, arsitektur, farmasi, geografi, ekonomi, dan sebagainya". Akan tetapi, sebuah jurnal yang ditulis oleh Mahdiansyah dan Rahmawati (2014:453), menyatakan bahwa "Pada Programme for International Student Assessment (PISA) 2012 capaian literasi matematika siswa Indonesia semakin terpuruk menjadi peringkat 64 dari 65 negara”. Berdasarkan penjelasan di atas, tampak bahwa pembelajaran matematika siswa di Indonesia masih jauh dari apa yang diharapkan.

Keadaan di atas juga tampak pada saat melakukan wawancara kepada Pak Sukran, selaku guru matematika MTs Al-Washliyah 16 Perbaungan, bahwa pada pembelajaran matematika, nilai siswa dalam pembelajaran matematika masih rendah dan siswa jarang diberikan soal pemecahan masalah, maka dari itu kemampuan pemecahan masalah matematika siswa masih rendah.

Hal ini dikarenakan siswa jarang diberi soal pemecahan masalah, sehingga mereka tidak terbiasa menyelesaikan soal-soal pemecahan masalah dengan baik. Disamping itu, pembelajaran secara kooperatif (kelompok) jarang dilakukan. Padahal untuk mendukung siswa menyelesaikan suatu permasalahan matematika, sangat baik bila dilakukan pembelajaran secara kooperatif, agar permasalahan yang dihadapi dapat diselesaikan dengan mudah secara bersama.

Melihat keadaan di atas, maka penggunaan model pembelajaran kooperatif diharapkan dapat membawa dampak positif terhadap permasalahan yang ada. Untuk membantu menumbuh kembangkan kemampuan pemecahan masalah matematika siswa, maka penggunaan model kooperatif tipe jigsaw dapat mengatasi hal tersebut. Sama seperti menurut Hamdani (2011:31) bahwa "Dalam pembelajaran kooperatif siswa belajar bersama dalam kelompok-kelompok kecil yang saling membantu satu sama lain". Dengan demikian, menyelesaikan suatu permasalahan, akan terasa mudah jika dilakukan secara bersama-sama.

$$
\text { Rusman (2011:202) menyatakan, }
$$

"Pembelajaran kooperatif merupakan pembelajaran dengan cara siswa belajar dan bekerja dalam kelompok-kelompok kecil secara kolaboratif yang beranggotakan empat sampai enam orang yang bersifat heterogen". Satu diantara tipe-tipe model pembelajaran kooperatif adalah Jigsaw. Dan berdasarkan penjelasan Aronson (dalam Riyanto, 2012:19), "Esensi Jigsaw adalah tiap siswa dalam kelompok memiliki satu potongan informasi khusus yang masing-masing berbeda, kemudian dia bertanggung jawab untuk mengajarkannya pada teman satu kelompoknya, dan ketika gambaran informasi ini bergabung, siswa memiliki satu puzzle yang utuh". Dengan demikian, siswa dapat menumbuh kembangkan kemampuan pemecahan masalah matematika mereka, secara individu maupun kelompok.

\section{B. Metode Penelitian}

Populasi dalam penelitian ini adalah seluruh siswa MTs Al-washliyah 16 Perbaungan. Sampel pada penelitian ini adalah kelas VIIA-1 berjumlah 36 siwa dan kelas VIIA-2 berjumlah 36 siswa TA 2018-2019. Untuk menentukan sampel, peneliti menggunakan teknik simple random sampling, yaitu pengambilan anggota sampel dari populasi secara acak tanpa memperhatikan strata yang ada dalam populasi tersebut. Adapun rancangan/desain penelitian yang digunakan adalah pretest-posttest control group design. Rancangan/desain ini melibatkan dua kelas, yaitu kelas eksperimen dan kontrol yang diberi perlakuan yang berbeda. Terlebih dahulu kelas eksperimen diberikan pretest, kemudian pembelajaran menggunakan model kooperatif tipe Jigsaw, kemudian posttest. Selanjutnya kelas kontrol diberikan pretest, dengan pembelajaran menggunakan model konvensional, kemudian diberikan posttest. Rancangan/desain penelitian tersebut dapat dilihat pada table 1 berikut :

Tabel 1. Pretest-Posttest Conrol Group

Design
\begin{tabular}{|c|c|c|c|}
\hline Kelas & Pretes & Perlakuan & Postes \\
\hline Eksperimen & $\mathrm{T}_{1}$ & $\mathrm{X}_{1}$ & $\mathrm{~T}_{3}$ \\
\hline Kontrol & $\mathrm{T}_{2}$ & $\mathrm{X}_{2}$ & $\mathrm{~T}_{4}$ \\
\hline
\end{tabular}

\section{Hasil dan Pembahasan}

Analisis yang digunakan adalah analisis statistik deskriptif dan analisis statistika inferensial. Analisis statistik deskriptif digunakan untuk menganalisis secara deskriptif terdapat 
pengaruh pembelajaran kooperatif jigsaw terhadap kemampuan pemecahan masalah matematika siswa MTs Al-Washliyah 16 Perbaungan. Analisis statistika inferensial digunakan untuk menguji hipotesis dalam penelitian ini dengan menganalisis data pengaruh pembelajaran kooperatif jigsaw terhadap kemampuan pemecahan masalah matematika siswa MTs Al-Washliyah 16 Perbaungan. Pada pengolahan data peneliti menggunakan perangkat lunak Microsoft Ofice Excel 2007 dan SPSS 21,0.

Adapun rata-rata pretes berdasarkan aspek pemecahan masalah yang meliputi (a) memahami masalah, (b) menyusun rencana pemecahan masalah, (c) melaksanakan pemecahan masalah sesuai rencana, dan (d) memeriksa kembali hasil pemecahan masalah untuk kelas eksperimen berturut-turut adalah 50,$7 ; 22 ; 148,6$; dan 76,7. Sedangkan untuk kelas kontrol berturut-turut adalah 50,$7 ; 20,6 ; 146,1$; dan 76 . Data pretest kedua kelas sampel berdasarkan aspek pemecahan masalah sebagai berikut:

Tabel 2. Hasil Perhitungan Statistik Pretest Berdasarkan Aspek Pemecahan Masalah Kelas Eksperimen dan Kelas Kontrol

\begin{tabular}{|c|c|c|c|c|c|c|c|c|}
\hline \multirow{2}{*}{$\begin{array}{c}\text { Statistik } \\
\text { A }\end{array}$} & \multicolumn{3}{|c|}{ Kelas Eksperimen } & \multicolumn{4}{|c|}{ Kelas Kontrol } \\
\cline { 2 - 9 } & a & b & C & D & a & b & C & d \\
\hline N & 36 & 36 & 36 & 36 & 36 & 36 & 36 & 36 \\
\hline Nilai & 1825 & 792 & 5350 & 2763 & 1825 & 742 & 5258 & 2738 \\
\hline Rata2 & 50,7 & 22 & 148,6 & 76,7 & 50,7 & 20,6 & 146,1 & 76 \\
\hline
\end{tabular}

Setelah diperoleh kemampuan awal masingmasing siswa, selanjutnya dibentuk kelompok heterogen dari kelas eksperimen sesuai model pembelajaran yang digunakan yaitu kooperatif tipe jigsaw. Adapun kelompok yang terbentuk dari kelas eksperimen sebanyak 9 kelompok asal dengan jumlah anggota dari setiap kelompoknya terdiri dari 4 orang. Kemudian, ketika pembelajaran berlangsung, kelompok asal berpencar sesuai tugas yang diberikan sehingga membentuk kelompok ahli. Sedangkan untuk kelas kontrol dengan model pembelajaran konvensional tidak dibentuk kelompok.

Setelah diketahui kemampuan awal dan dibentuk kelompok bagi kelas eksperimen, dilakukan persiapan berupa penetapan jadwal, penyusunan RPP, LAS, media, dan postest. Selanjutnya dilakukan pembelajaran dengan menggunakan dua model pembelajaran yang berbeda pada kedua kelas sampel, yaitu kooperatif tipe jigsaw pada kelas eksperimen dan konvensional pada kelas kontrol. Pada pertemuan terakhir, siswa kelas eksperimen dan kontrol diberikan postes dengan tujuan untuk mengetahui kemampuan pemecahan masalah matematika dari kedua kelas tersebut.

Adapun rata-rata postes berdasarkan aspek pemecahan masalah yang meliputi (a) memahami masalah, (b) menyusun rencana pemecahan masalah, (c) melaksanakan pemecahan masalah sesuai rencana, dan (d) memeriksa kembali hasil pemecahan masalah untuk kelas eksperimen berturut-turut adalah 82,3; 74,8; 292,6; dan 163. Sedangkan untuk kelas kontrol berturut-turut adalah 82,$6 ; 69 ; 272,2$; dan 159 . Data postes berdasarkan aspek pemecahan masalah kedua kelas sampel tersebut dapat dilihat pada tabel berikut ini:

Tabel 3. Hasil Perhitungan Statistik Postes Berdasarkan Aspek Pemecahan Masalah Kelas Eksperimen dan Kelas Kontrol

\begin{tabular}{|c|c|c|c|c|c|c|c|c|}
\hline \multirow{2}{*}{$\begin{array}{c}\text { Statistik } \\
\text { B }\end{array}$} & \multicolumn{3}{|c|}{ Kelas Eksperimen } & \multicolumn{4}{c|}{ Kelas Kontrol } \\
\cline { 2 - 9 } & a & b & C & D & A & b & C & d \\
\hline N & 36 & 36 & 36 & 36 & 36 & 36 & 36 & 36 \\
\hline Nilai & 2963 & 2692 & 10533 & 5863 & 2975 & 2483 & 9800 & 5725 \\
\hline Rata2 & 82,3 & 74,8 & 292,6 & 163 & 82,6 & 69 & 272,2 & 159 \\
\hline
\end{tabular}

Berdasarkan hasil perhitungan statistik, tampak keadaan belajar kelas eksperimen yang melakukan pembelajaran menggunakan model kooperatif tipe Jigsaw lebih baik dibandingkan dengan keadaan belajar kelas kontrol yang melakukan pembelajaran menggunakan model konvensional. Hal ini disebabkan karena pada kelas eksperimen, diberi perlakuan berupa model pembelajaran kooperatif tipe jigsaw sehingga memudahkan siswa menyelesaikan permasalahan dalam waktu yang cukup singkat dan secara bersama-sama. Selain itu, siswa dilatih menjadi ahli dalam menyelesaikan permasalahan. sehingga pembelajaran menggunakan model kooperatif tipe jigsaw memberikan pengaruh positif kepada siswa kelas eksperimen. Hal tersebut didukung dengan hasil postest yang menyatakan bahwa jumlah nilai dan rata-rata nilai postest kelas eksperimen lebih tinggi dibandingkan dengan jumlah nilai dan rata-rata nilai postest kelas kontrol seperti yang telah dijelaskan sebelumnya. 
Sedangkan di kelas kontrol yang melakukan pembelajaran menggunakan model konvensional, tidak seperti kelas eksperimen. Pada kelas kontrol diberikan model konvensional yang sebenarnya tidak diberikan perlakuan apapun dalam pembelajaran. Sehingga tampak siswa kebingungan dan merasa kesulitan dalam menyelesaikan permasalahan yang disajikan baik LAS maupun tes. Tidak ada kerja sama dan interaksi yang membantu penyelesaian permasalahan. Interaksi yang terjadi hanya tanya jawab antara siswa dan guru serta pada saat presentasi. Sehingga, daya serap siswa kelas kontrol menjadi rendah. Hal tersebut didukung dengan hasil postest yang menyatakan bahwa jumlah nilai dan rata-rata nilai postest kelas kontrol lebih rendah dibandingkan jumlah nilai dan rata-rata nilai postes kelas eksperimen.

Hal tersebut dapat dilihat pada tabel 2 dibawah ini:

\begin{tabular}{|c|c|c|c|}
\hline $\begin{array}{c}\text { Pretes } \\
\text { Eksperimen }\end{array}$ & $\begin{array}{c}\text { Postes } \\
\text { Eksperimen }\end{array}$ & $\begin{array}{c}\text { Pretes } \\
\text { kontrol }\end{array}$ & $\begin{array}{c}\text { Postes } \\
\text { Kontrol }\end{array}$ \\
\hline 37,29 & 75,76 & 36,60 & 69,17 \\
\hline \multicolumn{2}{|c|}{ Kenaikan Sebesar 38,47} & \multicolumn{3}{|c|}{ Kenaikan Sebesar 32,57 } \\
\hline
\end{tabular}

Dengan demikian, dapat disimpulkan kembali bahwa model pembelajaran kooperatif tipe jigsaw berpengaruh positif terhadap kemampuan pemecahan masalah matematika pada materi bilangan pecahan. Selain itu model pembelajaran kooperatif tipe Jigsaw lebih baik dibandingkan dengan model pembelajaran konvensional pada penelitian ini.

\section{Kesimpulan dan Saran}

\section{Kesimpulan}

Kesimpulan bahwa terdapat pengaruh model pembelajaran kooperatif tipe Jigsaw terhadap kemampuan pemecahan masalah matematika siswa kelas VII MTs Al Washliyah 16 Perbaungan materi bilangan pecahan tahun pembelajaran 2018-2019. Hal tersebut didukung dengan kemampuan pemecahan masalah matematika siswa kelas eksperimen lebih tinggi daripada kemampuan pemecahan masalah matematika kelas kontrol setelah diberikan pembelajaran dan postest. Hal ini diketahui berdasarkan perbandingan jumlah nilai dan rata-rata postest kedua kelas sampel, yaitu jumlah nilai kelas eksperimen $=2727,5>$ jumlah nilai kelas kontrol $=2490$, dan rata-rata kelas eksperimen $=75,76>$ rata-rata kelas kontrol $=69,17$.

\section{Saran}

a. Kepada guru matematika, dapat menggunakan model pembelajaran kooperatif tipe jigsaw sebagai salah satu alternatif pembelajaran matematika, karena pembelajaran ini mempunyai potensi untuk meningkatkan kemampuan pemecahan masalah matematika siswa. Bahan ajar yang diberikan dalam pembelajaran harus disajikan dalam bentuk yang menarik serta menggunakan bahasa yang sederhana dan efektif sehingga siswa lebih tertarik dalam mempelajarinya, tidak merasa bosan dan lebih termotivasi untuk belajar matematika.

b. Kepada siswa MTs atau sederajat, secara khusus siswa kelas VII MTs Al Washliyah 16 Perbaungan, disarankan untuk saling bekerja sama dalam diskusi kelompok terutama dalam memecahkan masalah yang berhubungan dengan materi pelajaran matematika.

\section{E. Daftar Pustaka}

Abdurrahman, Mulyono. 2012. Pendidikan Bagi Anak Berkesulitan Belajar. Jakarta: Rineka Cipta.

Arikunto, Suharsimi. 2003. Dasar-Dasar Evaluasi Pendidikan. Jakarta: Bumi Aksara.

Hamdani. 2011. Strategi Belajar Mengajar: Kata Pengantar: Dr. H. Abdul Kodir, M.Ag. Bandung: Pustaka Setia.

Rusman. 2011. Model-Model Pembelajaran: Mengembangkan Profesionalisme Guru. Jakarta:Rajawali Pers.

Riyanto, Agus. 2012. Efektivitas Model Cooperative Learning Tipe Jigsaw terhadap Hasil Belajar Mata Pelajaran IPS pada Siswa Kelas V Sekolah Dasar Negeri Pendowo 03 Semester II Kab. 
Juliana dkk, Pengaruh Pembelajaran Kooperatif Jigsaw ...

Temanggung Tahun Ajaran 2011/2012.

Salatiga: Universitas Kristen Satya

Wacana.

Rusman. 2011. Model-Model Pembelajaran:

Mengembangkan Profesionalisme

Guru. Jakarta:Rajawali Pers.

Suherman, Erman, dkk. 2001. Common Text Book: Strategi Pembelajaran Matematika Kontemporer. Bandung: JICA Universitas Pendidikan Indonesia (UPI).

Sudjana. 2005. Metoda Statistika. Bandung: Tarsito.

Suherman, Erman, dkk. 2001. Common Text Book: Strategi Pembelajaran

Matematika Kontemporer. Bandung:

JICA Universitas Pendidikan Indonesia (UPI).

Purwanto. 2011. Evaluasi Hasil Belajar.

Yogyakarta: Pustaka Pelajar. 